\title{
Illustration
}

\section{Necrotizing Fasciitis: Fatal Evolution of Acral Melanoma}

EI Marfi Abdelhafid, MD'*; Samia Mrabat, MD²; Kaoutar Laamari, MD²; Mohammed El Idrissi, PhD';Abdelhalim El Ibrahimi, PhD'; Abdelmajid El Mrini, PhD'; Zakia Douhi, MD²; Sara Elloudi, PhD²; Hanane Baybay, PhD²; Mernissi F. Zahra, PhD²

'Department of Traumatology and Orthopedic Surgery, University Hospital Hassan II, Fes, Morocco

${ }^{2}$ Department of Dermatology, University Hospital Hassan II, Fes, Morocco

\section{${ }^{*}$ Corresponding author}

\section{Abdelhafid EI Marfi, MD}

Department of Traumatology and Orthopedic Surgery, University Hospital Hassan II, Fes, Morocco;Tel. +2I2 678339879 ; Fax. 05356137 29;

E-mail: hafid.elmarfi@gmail.com

\section{Article information}

Received: November $7^{\text {th }}, 2019$; Revised: December 21 ${ }^{\text {st }}, 2019$; Accepted: January 18 $8^{\text {th }}, 2020$; Published: January $28^{\text {th }}, 2020$

\section{Cite this article}

El Marfi A, Mrabat S, Laamari K, et al. Necrotizing fasciitis: Fatal evolution of acral melanoma. Orthop Res Traumatol Open J. $2020 ; 5($ I): I-2.

doi: 10.17|40/ORTOJ-5-116

$\mathrm{N}$ ecrotizing fasciitis (NF) is a life-threatening soft tissue infection characterized by a rapidly spreading infection of the subcutaneous tissue and in particular the fascia. Early diagnosis and radical surgical debridement are required. Surgery is indicated if NF is clinically suspected and must not be delayed by diagnosis in order to reduce mortality. We report a case of NF following surgery of an acral melanoma. ${ }^{1,2}$

A 73-year-old patient, with a history of type 2 diabetes with a poor glycemic balance, was diagnosed with acral non metastatic pigmented melanoma of the fifth toe (Figure 1) and underwent surgery to excise the tumor. He was seen 10-days later with a painful and acute red leg along with signs of sepsis (fever, hypotension, tachycardia). Dermatological examination found an ill-limited oedematous erythematosus leg with large phlyctenes and necrotic areas extending from the back of the foot to the left leg (Figure 2). Palpation of the leg found crepitus and hypoesthetic zones. The member's X-ray showed an infiltration of the soft parts of the leg

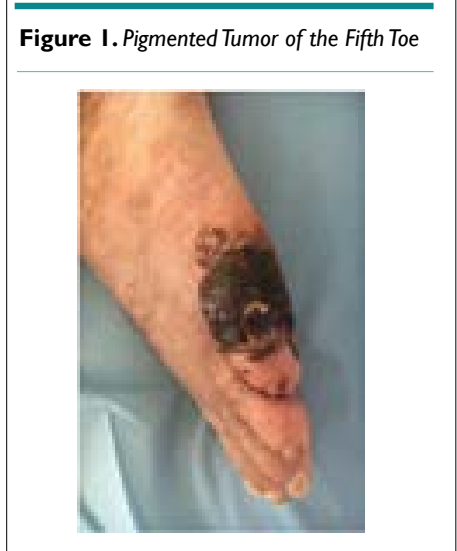

with the presence of air bubbles (Figure 3). As the diagnosis of necrotizing fasciitis was highly suspected, the patient underwent surgery (Figure 4) for an discharge aponevrotomy. He died hours later due to a septic shock.
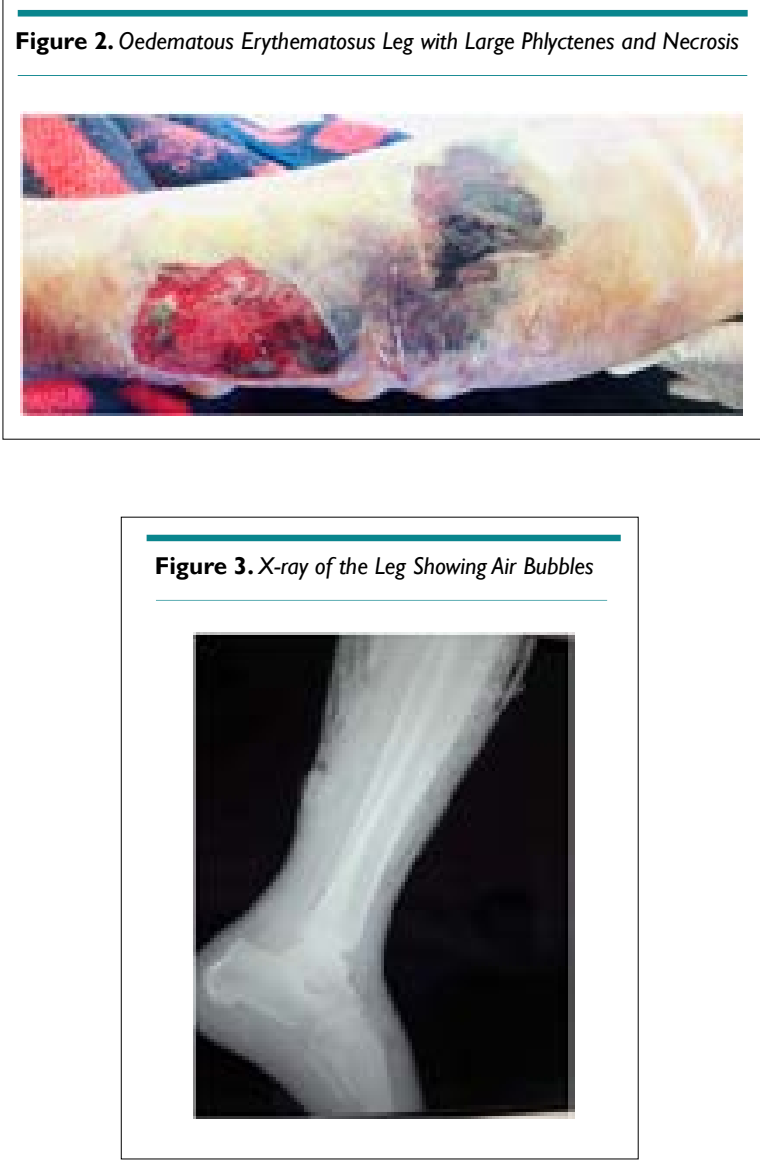


\section{CONFLICTS OF INTEREST}

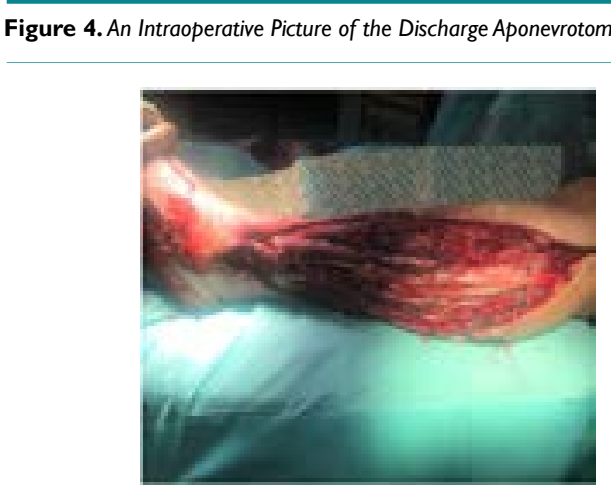

CONSENT

The authors have received written informed consent from the patient.
The authors declare that they have no conflicts of interest.

\section{REFERENCES}

1. Leiblein M, Marzi I, Sander AL, Barker JH, Ebert F, Frank J. Necrotizing fasciitis: Treatment concepts and clinical results. Eur J Trauma Emerg Surg. 2018; 44(2): 279-290. doi: 10.1007/s00068017-0792-8

2. Hakkarainen TW, Kopari NM, Pham TN, Evans HL. Necrotizing soft tissue infections: Review and current concepts in treatment, systems of care, and outcomes. Curr Probl Surg. 2014; 51(8): 344-362. doi: 10.1067/j.cpsurg.2014.06.001 